\begin{tabular}{|c|c|c|}
\hline & Int.J.Curr.Microbiol.App.Sci (2021) 10(12): $72-79$ & \\
\hline & $\begin{array}{l}\text { International Journal of Current Microbiology and Applied Sciences } \\
\text { ISSN: 2319-7706 Volume } \mathbf{1 0} \text { Number } \mathbf{1 2}(\mathbf{2 0 2 1 )} \\
\text { Journal homepage: http://www.ijcmas.com }\end{array}$ & 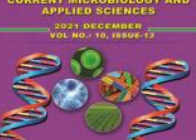 \\
\hline $\begin{array}{l}\text { EXCELLENT } \\
\text { PUBLISHERS }\end{array}$ & & \\
\hline
\end{tabular}

Original Research Article

https://doi.org/10.20546/ijcmas.2021.1012.009

\title{
Influence of Plant Growth Regulators and Jeevamrut on Morphological and Yield Parameters of Pigeonpea (Cajanus cajan L.)
}

\author{
Madhuri B. Dhomne*, D. V. Durge, Priti A. Sonkamble and T. H. Rathod \\ Department of Agricultural Botany, Dr. Panjabrao Deshmukh Krishi Vidyapeeth, \\ Akola-444001, Maharashtra, India \\ *Corresponding author
}

\begin{abstract}
A B S T R A C T
Keywords

Plant growth regulators,

Jeevamrut,

Morphological and yield parameters

Pigeonpea

Article Info

Received:

05 November 2021

Accepted:

28 November 2021

Available Online:

10 December 2021

A field experiment was conducted during kharif season 2018-19 and 201920 at Experimental field of Department of Agricultural Botany., Dr. Panjabro Deshmukh Krishi Vidyapeeth, Akola (M. S.). The experiment comprised of single variety of pigeonpea i.e. PKV (TARA) laid out in randomized block design with four replications, provided with eight treatments of two growth regulators i.e. $\mathrm{GA}_{3}-25,50$ and $75 \mathrm{ppm}$ and NAA25, 50 and 75 ppm concentrations including jeevvmrut@500 L ha ${ }^{-1}$ and control. Plant growth regulators at different concentrations were applied through foliar spray at flower and pod initiation stages and soil application of jeevamruth was carried out at 30,60, 90 and 120 DAS. Results indicated that two applications of $75 \mathrm{ppm} \mathrm{GA}_{3}$ at flower and pod initiation stages recorded significantly more plant height, leaf area plant ${ }^{-1}$, total dry matter production $^{-1}$ and yield and yield attributes followed by NAA-75 ppm and by soil application of jeevamruth @ 500 L ha-1.
\end{abstract}

\section{Introduction}

Pigeonpea is one of the major pulse crop cultivated in India. This crop is widely grown in India and India is the largest producer and consumer of pigeonpea in the world. It is a widely adapted, hardy and drought tolerant crop with a large temporal variation (90-300 days) for maturity. In India, pigeonpea is grown on 45.22 lakh hectares with production of 38.51 lakh tons with a productivity of 859 $\mathrm{kg} / \mathrm{ha}$ (Anonymous, 2020-21). Pre-mature abscission of flowers is one of the most serious problems in pigeonpea (Fakir 1997) and other legumes (Wiebold et al., 1981). Pigeonpea produces large number of flowers, of which as much as $90 \%$ are shed (Wasike et al., 2005). Therefore, the low yield of pigeonpea is due to poor pod set resulting from high flower and pod drops. 
The low yield in pigeonpea is also due to excessive vegetative growth, indeterminate growth habit, poor source-sink relationship, poor pod set resulting from high flower and pod drops. Therefore, it is very necessary to compensate the high degree of flower abscission in pigeonpea and increase the pod yield. Plant growth regulators (PGR's) are considered as new generation of agro chemicals after fertilizers, pesticides and herbicides to augment seed yield and quality. They are also known to enhance the source sink-relationship and stimulate the translocation of photo assimilates thereby resulting in better retention of flowers and fruits. Secondly, indigenous liquid organic manures such as beejamrutha, jeevamrutha, panchagavya, amruthpani, liquid biodigester, biogas slurry etc., play major role in improving growth and yield of crops. These solutionsare rich source of useful and effective microorganisms and also contain both macro nutrients and essential micro nutrients, many vitamins, essential amino acids, growth promoting substances like indole acetic acid (IAA), gibberellic acid (GA) (Palekar, 2006; Sreenivasa et al., 2010). Taking above view into consideration the present investigation was carried out with the objective to study the responses of plant growth regulators and jeevamrut on morphological and yield attributes in pigeonpea.

\section{Materials and Methods}

The present investigation was conducted under field condition during kharif season 2018-19 and 2019-20 at Experimental field of Department of Agricultural Botany., Dr. Panjabro Deshmukh Krishi Vidyapeeth, Akola (M. S.). The experiment comprised of single variety of pigeonpea i.e. PKV (TARA) laid out in randomized block design with four replications, provided with eight treatments of two growth regulators i.e. $\mathrm{GA}_{3}-25,50$ and 75 ppm and NAA-25, 50 and 75 ppm concentrations including jeevvmruth and control. Spraying of growth regulators was done at flower initiation stage (stage 1) and pod initiation stage (stage 2) and soil application of jeevamrut was done at 306090 and 120 DAS. The plot size was $4.6 \mathrm{~m} \mathrm{x} 4.0 \mathrm{~m}$. Seeds of pigeonpea were sown at spacing of $60 \mathrm{~cm}$ between rows and $20 \mathrm{~cm}$ between plants. After the emergence of seedling, only one healthy seedling was maintained per hill to obtain uniform planting density. $\mathrm{N}, \mathrm{P}$ and $\mathrm{K}$ fertilizers in the form of urea, single super phosphate and muriate of potash were applied @ $25 \mathrm{~kg} \mathrm{~N}+50 \mathrm{~kg} \mathrm{P}_{2} \mathrm{O}_{5}+20 \mathrm{~kg} \mathrm{~K}_{2} \mathrm{O} \mathrm{ha}^{-1}$ to the gross plots. Half dose of $\mathrm{N}$ and a complete dose of $\mathrm{P}_{2} \mathrm{O}_{5}$ and $\mathrm{K}_{2} \mathrm{O}$ were given as a basal dose at sowing while the remaining $\mathrm{N}$ was applied at 18 days after sowing. Plant protection measures were adopted as and when needed. Spray of quinalphos 25 EC @ $1000 \mathrm{ml}$ ha-1 was done to reduce the infestation of pod borer for growth regulators treatments and for jeevamrut treatments spraying of decoction prepared form plant samples and cow urine was done to reduce the infestation of insects. Observations were recorded at different stages i.e.60, 90, 120DAS and at Maturity. Harvesting in all treatments was undertaken after maturity of crop.

\section{Results and Discussion}

\section{Morphological parameters}

In the present investigation plant height plant ${ }^{-}$ 1 , recorded substantial increase at 120 DAS and at maturity i.e. after the two foliar applications of $75 \mathrm{ppm} \mathrm{GA}_{3}(208.66 \mathrm{~cm})$ at flower and pod initiation stages followed by foliar application of NAA 75ppm $(204.96 \mathrm{~cm})$ at flower and pod initiation stages and soil application of jeevamrut @ $500 \mathrm{~L} \mathrm{ha}^{-1}$ at 30 , 60, 120 DAS $(204.87 \mathrm{~cm})$ as shown in Table 1. These results are in conformity with researchers those reported that, application of 
growth regulator also enhances the absorption and transport of nutrients. Hence, it facilitates fast availability of nutrient and growth of the plant. These might be the reasons for increasing the plant height in the present investigation. Increase in plant height may be due to the fact that $\mathrm{GA}_{3}$ increased the growth of plant by increasing intermodal length and due to cell division, cell enlargement and enhanced apical dominance indirectly by increasing auxin content and thus indirectly helped to increase the seed yield. Similar results were obtained by Giri et al., (2018) and Yogita Chinnmalwar et al., (2017) in pigeonpea.

Data regarding leaf area was recorded at 30 days interval from 60, 90, 120 DAS and at maturity. It was observed that leaf area per plant progressively increased up to 120 DAS, later on it decline towards the maturity as shown in Table 2. At 60 DAS the data regarding leaf area per plant was found non significant. At 90 DAS significantly higher leaf area was noted by treatment $\left(\mathrm{T}_{4}\right)$ foliar application of $\mathrm{GA}_{3}-75 \mathrm{ppm}$ at flower initiation and pod initiation stages. $\left(36.533 \mathrm{dm}^{2}\right)$. However, at 120 DAS significantly superior leaf area plant ${ }^{-1}$ was exhibited by the treatment $\left(\mathrm{T}_{7}\right)$ foliar application of NAA-75ppm $\left(54.644 \mathrm{dm}^{2}\right)$ at flower initiation and pod initiation stages followed by spraying of $\mathrm{GA}_{3}-$ $75 \mathrm{ppm}\left(\mathrm{T}_{4}\right)$ treatment $\left(49.851 \mathrm{dm}^{2}\right)$ and $\mathrm{T}_{8}$ treatment $\left(44.795 \mathrm{dm}^{2}\right)$ i.e. soil application of jeevamrut-@500 L ha ${ }^{-1}$. It is observed that leaf area significantly increased after application of treatments. Similar results were obtained by Sutar V. K. (2019) in pigeonpea and Korade et al., (2019) in wheat.

Table.1 Effect of Plant Growth Regulators and Jeevamrut on Plant height plant ${ }^{-1}$ at maturity $(\mathrm{cm})$

\begin{tabular}{|c|c|c|c|}
\hline \multicolumn{4}{|c|}{ Plant height } \\
\hline Treatments & Kh-2018-19 & Kh-2019-20 & Pooled \\
\hline $\mathbf{T}_{1}$ (Control) & 173.95 & 192.35 & 183.15 \\
\hline $\mathbf{T}_{2}-\mathbf{G A}_{3}-25 P P M$ & 182.14 & 223.56 & 202.85 \\
\hline $\mathrm{T}_{3}-\mathrm{GA}_{3}$ 50PPM & 184.46 & 225.18 & 204.82 \\
\hline $\mathbf{T}_{4}-\mathbf{G A}_{3-}$ 75PPM & 188.60 & 228.71 & 208.66 \\
\hline $\mathrm{T}_{5}$-NAA-25PPM & 183.62 & 222.05 & 202.83 \\
\hline T $_{6}$-NAA-50PPM & 184.37 & 223.78 & 204.07 \\
\hline T $_{7}$-NAA-75PPM & 185.27 & 224.65 & 204.96 \\
\hline T8-Jeevamrut @ 500 L ha ${ }^{-1}$ & 179.51 & 230.23 & 204.87 \\
\hline Mean & 182.74 & 221.31 & 202.03 \\
\hline $\mathbf{S E}(\mathbf{m}) \pm$ & 0.969 & 0.999 & 0.725 \\
\hline CD at $5 \%$ & 2.851 & 2.937 & 2.133 \\
\hline
\end{tabular}


Table.2 Effect of Plant Growth Regulators and Jeevamrut on Leaf area in pigeonpea $\left(\mathrm{dm}^{2}\right)$

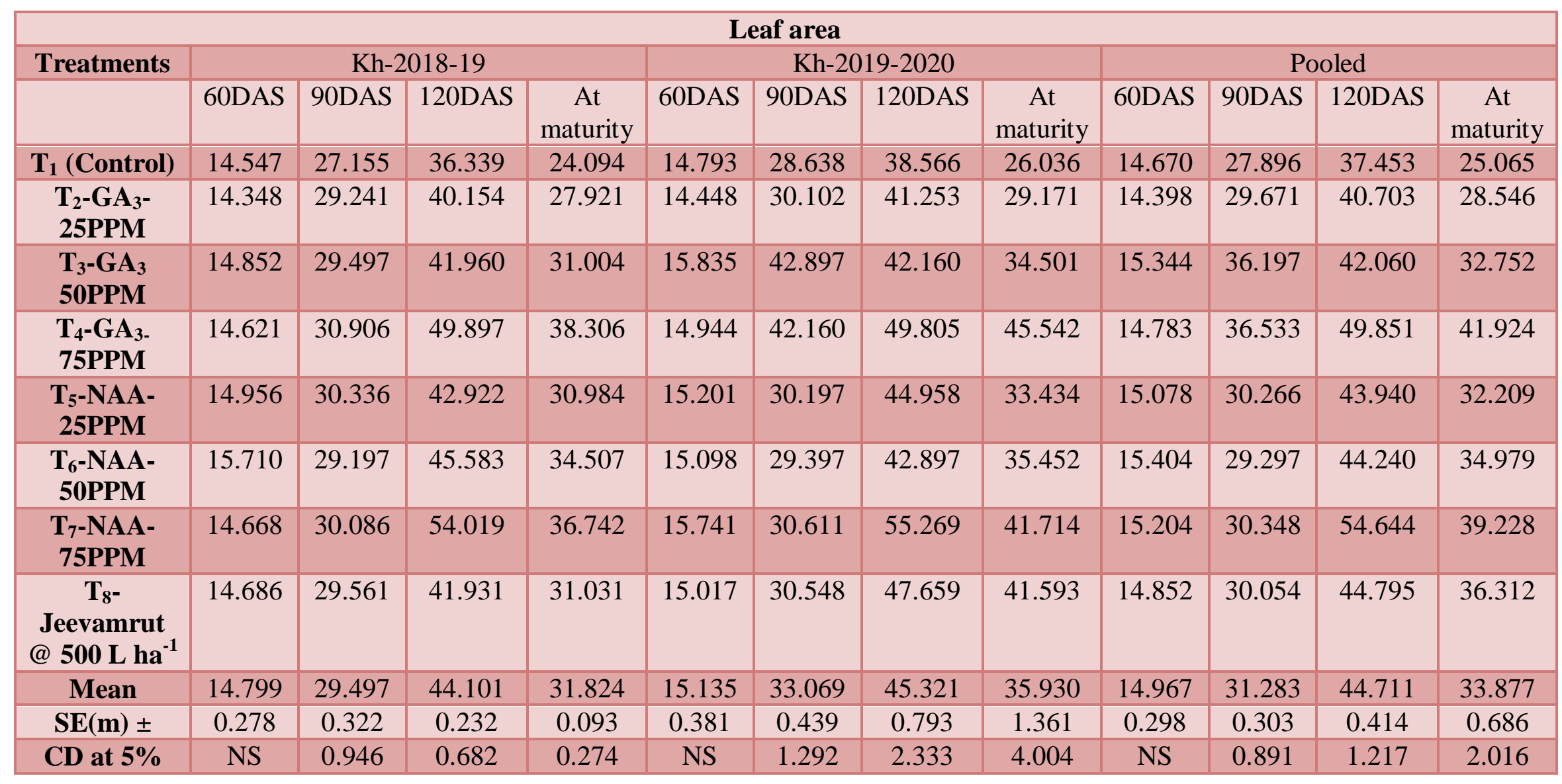


Table.3 Effect of Plant Growth Regulators and Jeevamrut on dry weight plant ${ }^{-1}$ in pigeonpea $(\mathrm{g})$

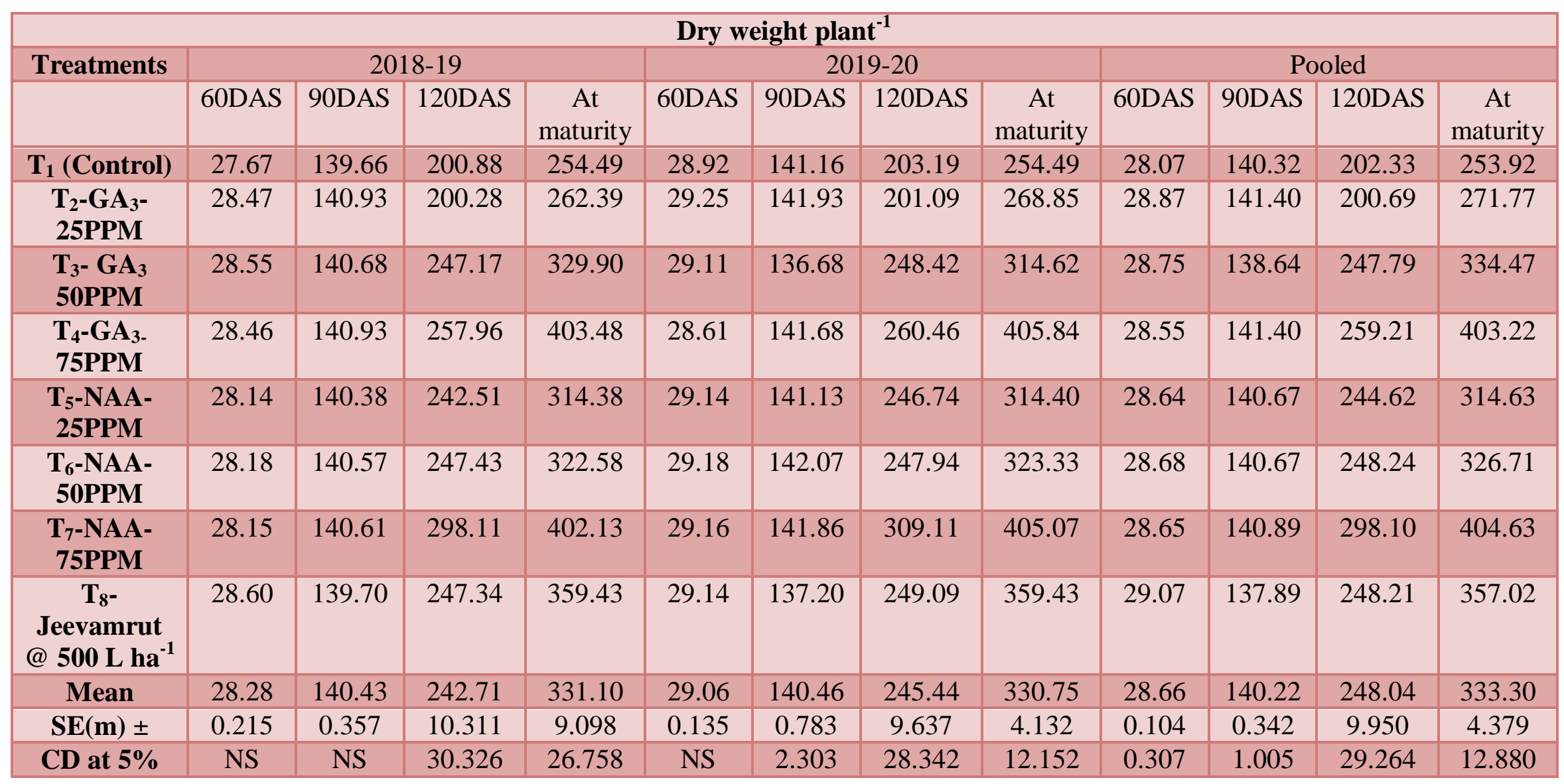


Table.4 Effect of Plant Growth Regulators and Jeevamruton number of pods plant ${ }^{-1}$, number of seeds pod ${ }^{-1}$ and 100 seed wt. (g)in Pigeonpea

\begin{tabular}{|c|c|c|c|c|c|c|c|c|c|c|c|c|c|c|c|}
\hline \multirow[t]{2}{*}{ Treatments } & \multicolumn{5}{|c|}{ 2018-19 } & \multicolumn{5}{|c|}{ 2019-20 } & \multicolumn{5}{|c|}{ Pooled } \\
\hline & $\begin{array}{l}\text { No. of } \\
\text { Pods } \\
\text { per } \\
\text { Plant }\end{array}$ & $\begin{array}{c}\text { No. of } \\
\text { seeds } \\
\text { per } \\
\text { pod }\end{array}$ & $\begin{array}{c}100 \\
\text { seed } \\
\text { wt. } \\
(\mathrm{g})\end{array}$ & $\begin{array}{l}\text { Seed } \\
\text { Yield } \\
\text { q/ha }\end{array}$ & $\begin{array}{l}\text { Harvest } \\
\text { Index }\end{array}$ & $\begin{array}{l}\text { No. of } \\
\text { Pods } \\
\text { per } \\
\text { Plant }\end{array}$ & $\begin{array}{c}\text { No. } \\
\text { of } \\
\text { seeds } \\
\text { per } \\
\text { pod }\end{array}$ & $\begin{array}{c}100 \\
\text { seed } \\
\text { wt. } \\
(\mathrm{g})\end{array}$ & $\begin{array}{l}\text { Seed } \\
\text { Yield } \\
\text { q/ha }\end{array}$ & $\begin{array}{c}\text { Harvest } \\
\text { Index }\end{array}$ & $\begin{array}{c}\text { No. of } \\
\text { Pods } \\
\text { per } \\
\text { Plant }\end{array}$ & $\begin{array}{c}\text { No. } \\
\text { of } \\
\text { seeds } \\
\text { per } \\
\text { pod }\end{array}$ & $\begin{array}{c}100 \\
\text { seed } \\
\text { wt. } \\
(\mathrm{g})\end{array}$ & $\begin{array}{l}\text { Seed } \\
\text { Yield } \\
\text { q/ha }\end{array}$ & $\begin{array}{c}\text { Harvest } \\
\text { Index }\end{array}$ \\
\hline $\mathbf{T}_{1}$ (Control) & 190.43 & 2.72 & 9.23 & 17.70 & 32.01 & 192.43 & 2.73 & 9.32 & 18.34 & 32.17 & 191.43 & 2.72 & 9.27 & 18.02 & 32.09 \\
\hline $\begin{array}{l}\text { T }_{2}-G_{A_{3}} \\
25 P P M\end{array}$ & 208.23 & 3.31 & 9.31 & 18.48 & 33.51 & 230.41 & 3.41 & 9.33 & 19.33 & 33.45 & 219.32 & 3.36 & 9.32 & 18.90 & 33.49 \\
\hline $\begin{array}{l}\mathbf{T}_{3}-\mathbf{G A}_{3} \\
\text { 50PPM }\end{array}$ & 233.52 & 3.34 & 9.39 & 18.83 & 32.38 & 238.51 & 3.61 & 9.43 & 19.79 & 32.17 & 236.02 & 3.47 & 9.41 & 19.31 & 32.24 \\
\hline $\begin{array}{l}\mathbf{T}_{4}-\mathbf{G A}_{3-} \\
\text { 75PPM }\end{array}$ & 248.40 & 3.85 & 9.85 & 20.38 & 33.72 & 250.58 & 3.86 & 9.86 & 22.25 & 34.12 & 249.69 & 3.89 & 9.86 & 21.31 & 33.93 \\
\hline $\begin{array}{l}\text { T}_{5} \text {-NAA- } \\
\text { 25PPM }\end{array}$ & 225.40 & 3.46 & 9.31 & 18.85 & 33.44 & 228.53 & 3.59 & 9.32 & 19.27 & 33.48 & 226.97 & 3.52 & 9.31 & 19.06 & 33.46 \\
\hline $\begin{array}{l}\text { T6-NAA- } \\
\text { 50PPM }\end{array}$ & 231.65 & 3.59 & 9.38 & 18.83 & 32.32 & 233.65 & 3.60 & 9.39 & 19.57 & 32.42 & 232.60 & 3.59 & 9.38 & 19.20 & 32.37 \\
\hline $\begin{array}{c}\text { T } \text { T-NAA- }^{\text {75PPM }} \\
\text { 75P }\end{array}$ & 241.26 & 3.76 & 9.42 & 19.07 & 32.36 & 244.20 & 3.78 & 9.44 & 19.99 & 32.44 & 242.73 & 3.77 & 9.43 & 19.53 & 32.41 \\
\hline $\begin{array}{c}\mathbf{T}_{8^{-}} \\
\text {Jeevamruth- } \\
\text { @ } 500 \text { L ha }^{-1}\end{array}$ & 233.52 & 3.64 & 9.53 & 18.62 & 33.63 & 247.61 & 3.72 & 9.64 & 20.92 & 34.86 & 240.56 & 3.68 & 9.58 & 19.77 & 34.25 \\
\hline Mean & 226.31 & 3.46 & 9.43 & 18.85 & 32.92 & 233.24 & 3.54 & 9.47 & 19.93 & 33.14 & 229.78 & 3.50 & 9.45 & 19.39 & 33.03 \\
\hline $\mathrm{SE}(\mathrm{m}) \pm$ & 1.22 & 0.07 & 0.08 & 0.064 & 0.16 & 1.37 & 0.09 & 0.08 & 0.209 & 0.14 & 0.88 & 0.06 & 0.06 & 0.101 & 0.12 \\
\hline CD at $5 \%$ & 3.59 & 0.21 & 0.22 & 0.188 & 0.48 & 4.04 & 0.26 & 0.23 & 0.615 & 0.43 & 2.58 & 0.18 & 0.20 & 0.297 & 0.34 \\
\hline
\end{tabular}


Total dry matter production rate plant $^{-1}$ progressively increased from 90 DAS up to maturity. At maturity the range of total dry matter was varied from 253.92 to $403.22 \mathrm{~g}$. A marked increase in total dry production plant $^{-1}$ was observed after the foliar application of growth regulators at flower initiation and pod initiation stages and soil application of jeevamrut at 30, 60, 90 and 120 DAS as shown in Table 3. Statistical analysis showed that foliar application of NAA-75ppm $\left(\mathrm{T}_{7}\right)$ i.e.404.63 $\mathrm{g}$ at flower initiation and pod initiation stages exhibited significantly higher total dry matter per plant followed by treatment $\left(\mathrm{T}_{4}\right)$ foliar application of $\mathrm{GA}_{3}-$ $75 \mathrm{ppm}(403.22 \mathrm{~g})$ and by soil application of jeevamrut- @ $500 \mathrm{~L} \mathrm{ha}^{-1}(357.02 \mathrm{~g})$ as compared to control (253.92 g) and rest of the treatments. Whereas, foliar application of $\mathrm{GA}_{3}-75 \mathrm{ppm}\left(\mathrm{T}_{4}\right)$ i.e. $403.22 \mathrm{~g}$ at flower initiation and pod initiation stages was at par with foliar application of treatment NAA$75 \mathrm{ppm}\left(\mathrm{T}_{7}\right)$ i.e. $404.63 \mathrm{~g}$ at flower initiation and pod initiation stages. Similar results were obtained by Upaydhyay and Rajan (2015) in soybean and Nabi et al., (2016) in cowpea.

\section{Yield and yield parameters}

Application of $\mathrm{GA}_{3}-75 \mathrm{ppm}$ recorded significantly more number of pods plant ${ }^{-1}$ and seeds $\operatorname{pod}^{-1}$ (249.69 and 3.89) followed by treatment $\left(\mathrm{T}_{7}\right)$, foliar application of NAA$75 \mathrm{ppm}$ (242.73 and 3.77) at flower and pod initiation stages and by treatment (T8) soil application of jeevamrut@ $500 \mathrm{~L} \mathrm{ha}^{-1}$ (240.56 and 3.68) at 30,60, 90, and 120 DAS and as compared to control (191.43 and 2.72) and rest of the treatments. Application of $\mathrm{GA}_{3}-$ $75 \mathrm{ppm}(9.86 \mathrm{~g})$ at flower and pod initiation stages recorded significantly highest 100 seed weight plant $^{-1}$ followed by $\mathrm{T}_{8}$ treatment soil application of jeevamrut@ $500 \mathrm{~L} \mathrm{ha}^{-1}(9.58 \mathrm{~g})$ at 30, 60, 90, and 120 DAS and by treatment $\mathrm{T}_{7}$, foliar application of NAA-75ppm (9.43 g) at flower and pod initiation stages as compared to control $(9.27 \mathrm{~g})$ and rest of the treatments.

Application of $\mathrm{GA}_{3}-75 \mathrm{ppm}(21.31 \mathrm{q})$ at flower and pod initiation stages recorded significantly highest seed yield $\mathrm{ha}^{-1}$ (q) followed by $\mathrm{T}_{8}$ treatment, soil application of jeevamrut- @ $500 \mathrm{~L} \mathrm{ha}^{-1}(19.77 \mathrm{q})$ at $30,60,90$, and 120 DAS and by treatment $\left(\mathrm{T}_{7}\right)$ foliar application of NAA-75ppm (19.53 q) at flower and pod initiation stages as compared to control (18.02 q) and rest of the treatments. However in case of harvest index the treatment $\left(\mathrm{T}_{8}\right)$ soil application of jeevamrut- @ $500 \mathrm{~L} \mathrm{ha}^{-1}$ (34.25 $\%)$ at 30, 60, 90, and 120 DAS recorded significantly highest harvest index followed by treatment $\left(\mathrm{T}_{4}\right)$ foliar application of $\mathrm{GA}_{3}$ $75 \mathrm{ppm}(33.93 \%)$ at flower and pod initiation stages as compared to control and rest of the treatments as shown in Table 4. Seed yield is influenced by morphological parameters such as plant height, total dry matter production, leaf area, number of branches and test weight which are considered as yield contributing parameters. Seed yield is combined effect of yield attributing characters and physiological efficiency of plant during the investigation. Partitioning of assimilates in the plant during reproductive development is important for flower, fruit and seeds. Thus, crop yield can be increased either by increasing the total dry matter production or by increasing the proportion of economic yield (harvest index) or both (Gardner et al., 1988).Similar findings were in agreement with Giri et al., (2018) and Jadhav et al., (2017) in pigeonpea. The positive response of organic formulations was also reported by Deekshith Gowda et al., (2018) in groundnut.

\section{References}

Anonymous, Directorate of Economics \& Stat., Dept. of Ag. Cooperation \& Farmers Welfare, Ministry of Ag. \& Farmers Welfare, Govt. of India and Agril. Dept. of M.S.www.eands.dacnet.nic.in 2020-21. 
Deekshith Gowda P R, Dhanoji M M, Meena M K, Suma T C and Hasan Khan 2018.Influence of foliar organic nutrition on growth, yield and yield components of groundnut J. Farm Sci.,31(4): (401-404) 2018

Fakir M S A.1997 A study of morphophysiological selection criteria related to yield in pigeonpea. Ph.D.dissertation. University West Indies, Augustine, Trinidad.

Gardner F P, Pearce R B. and Michell R L. 1988. Transport and partitioning. In physiology of Crops plants. $2^{\text {nd }} \mathrm{Ed}$. Scientific publishers, Jodgpur. Pp. 58-95.

Giri, M D, Jaybhaye C P, Kanwade D. G. and Bharti Tijare 2018.Effect of foliar application of gibbrellic acid on pigeonpea [Cajanus cajan (L.)] under rainfed conditions. Journal of Pharmacognosy and Phytochemistry7(2): 617-620

Jadhav G N, Deotale R D, Gavhane D B, Chute K H. 2017. Implant of foliar sprays of polyamine (Putrescine) and NAA on chemical and biochemical parameters and yield of pigeonpea. Bull. Env.Pharmacol. Life Sci.,6 (3): 407-412

KoradeS B, Deotale R D, Jadhav N D, Guddhe V A and Thakre O G. 2019Effect of cow urine and NAA on morpho-physiological parameters and yield of wheat. J. Soils and Crops.29 (2) 274-279

Nabi A, Hawlader M H K, Hasan M M, Haque M Z, Rahaman M L, 2016. Growth and yield difference due to application of various levels of gibberellic acid in local and BARI falon-1. Progressive Agriculture 27 (2): 94-100.

Palekar, S. 2006. The Philosophy of Spiritual Farming, (Zero budget of Natural Farming, Amrit Subash Palekar, Amravati, Maharashtra.

Sreenivasa M N, Naik N M. and Bhat SN. 2010. Beejamruth: A source for beneficial bacteria. Karnataka J. Agric Sci.17(3):72-77

Sutar V K, Narkhede W N, Nayak S K, and Jadhav K T, 2020.Effect of land configuration, growth regulators and integrated nutrient management on yield and economics of pigeonpea. J. of Crop and Weed, 16(2): 227-232

Upadhyay and Ranjan R. 2015. Effect of growth hormones on morphological parameters, yield and quality of soybean (Glycine $\max \quad$ L.) during changing scenario of climate under mid hill condition of uttarakhand. Int. J. of Tropical Agriculture,33(2): 1899-1904

Wiebold W J, Ashley D A, Boerma H R. 1981. Reproductive abscission levels and patterns for eleven determinate soybean cultivars. Agron J.73:43-46.

Wasike S, Okori P, Rubaihayo P R. 2005. Genetic variability and relatedness of the Asian and African pigeonpea as revealed by AFLP. African J Biotechnol.4:122833

Yogita Chinmalwar, Deotale R D, Suryawanshi V J, Neware M R, 2017. Influence of cow urine and NAA on morphological parameters and yield of Pigeonpea. J. Soils and Crops. 27 (1):198-203

\section{How to cite this article:}

Madhuri B. Dhomne, D. V. Durge, Priti A. Sonkamble and Rathod, T. H. 2021. Influence of Plant Growth Regulators and Jeevamrut on Morphological and Yield Parameters of Pigeonpea (Cajanus cajan L.). Int.J.Curr.Microbiol.App.Sci. 10(12): 72-79. doi: https://doi.org/10.20546/ijcmas.2021.1012.009 